\section{A MORTE DE AEMILIUS PAULLUS EM CANA. FAZENDO DE HERÓI UM GENERAL DERROTADO (POLYBIUS 3.112-117)}

RESUMO: Os estudiosos modernos consideram Políbio uma fonte confiável de informação (por exemplo, WALBANK, 1957, p.16 e LEHMAN, 1967). O principal tema de sua narrativa são os acontecimentos políticos e militares que moldaram a ascensão de Roma ao poder no mundo mediterrâneo; embora apenas porçôes das suas histórias sobreviveram, a sua superioridade em relação a outras fontes cobrindo este período é geralmente consensual. Em um estudo clássico, E. Marsden analisa Políbio como historiador militar e chegou à conclusão de que era um narrador preciso de eventos militares (MARSDEN, 1974, p. 270-71). Seu relato da batalha de Canas é um bom exemplo, à medida que considera a descrição do combate melhor do que os relatos de Tito Lívio, assim como outras fontes posteriores. A reputação de Políbio como um historiador preciso é bem merecida, e não é o objetivo deste artigo afirmar o contrário. Sua reputação é provavelmente a razão pela qual os historiadores modernos aceitam sua descrição da função de Aemilius Paullus na luta em Canas, apesar de algumas contradições e adiçōes fictícias. $\mathrm{Na}$ verdade, uma análise detalhada da sua descrição da batalha mostra que o historiador grego, de fato, amplia o enaltecimento de Paullus, e que sua versão das açôes do cônsul no campo de batalha deve ser rejeitada.

PALAVRAS-CHAVE: Políbio, Historiografia, Canas, Aemilius Paullus.

THE DEATH OF AEMILIUS PAULLUS AT CANNAE. MAKING A HERO OUT OF A DEFEATED GENERAL. (POLYBIUS 3.112-117)

ABSTRACT: Most modern scholars consider Polybius to be a reliable historian and a trustworthy source of information

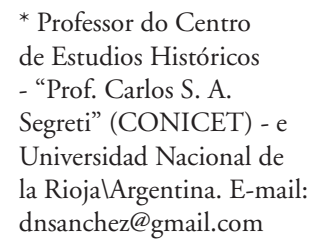


1. See, for example, Daly (2002, p. 18): “In the main, Polybius is to be regarded as the most important and accurate source for the battle of Cannae". See also Sabin (2007, p. 185). (see, for example, WALBANK, 1957, p.16 and LEHMAN, 1967). Indeed, he has even been described as being "superhumanly objective" (TOYNBEE, 1965, p. 472). The main subject of his narrative is the political and military events that shaped Rome's rise to power in the Mediterranean world. Although only portions of his Histories survive, their superiority over other sources covering this period is generally accepted. In a classic study, E. Marsden analysed Polybius as a military historian and reached the conclusion that he was an accurate reporter of military events (MARSDEN, 1974, p. 270-71). His account of the battle of Cannae is a good example of the high esteem in which he is held, as his description of the combat is considered better than those by Livy and other later sources. Polybius' reputation as an accurate historian is well deserved, and it is not the aim of this paper to affirm the contrary. His high standing is probably the reason why modern historians accept his description of Aemilius Paullus' role in the fighting at Cannae, notwithstanding some contradictions and fictitious additions. In fact, a detailed analysis of the Polybian account of the battle shows that the Greek historian evidently magnified the stature of Paullus, and that his version of the consul's actions on the battlefield should be rejected.

KEYWORDS: Polybius, Historiography, Cannae, Aemilius Paullus.

Most modern scholars consider Polybius to be a reliable historian and a trustworthy source of information (see, for example, WALBANK, 1957, p. 16 and LEHMAN, 1967). Indeed, he has even been described as being "superhumanly objective" (TOYNBEE, 1965, p. 472). The main subject of his narrative is the political and military events that shaped Rome's rise to power in the Mediterranean world. Although only portions of his Histories survive, their superiority over other sources covering this period is generally accepted. In a classic study, E. Marsden analysed Polybius as a military historian and reached the conclusion that he was an accurate reporter of military events (MARSDEN, 1974, p. 270-71). His account of the battle of Cannae is a good example of the high esteem in which he is held, as his description of the combat is considered better than those by Livy and other later sources. ${ }^{1}$ 
Polybius' reputation as an accurate historian is well deserved, and it is not the aim of this paper to affirm the contrary. His high standing is probably the reason why modern historians accept his description of Aemilius Paullus' role in the fighting at Cannae, notwithstanding some contradictions and fictitious additions. ${ }^{2}$ In fact, a detailed analysis of the Polybian account of the battle shows that the Greek historian evidently magnified the stature of Paullus, and that his version of the consul's actions on the battlefield should be rejected.

Cannae was a crucial event in the Second Punic War. It was Hannibal's greatest victory and one of the worst ever defeats of the Roman legions. In a brilliant display of superb tactical generalship, the Carthaginian commander succeeded against all the odds in encircling and annihilating the enemy in spite of being outnumbered. It is, without doubt, one of the most studied battles in history, and the amount of specialised literature concerning every aspect of the battle is enormous (see KROMAYER and VEITH, 1912, p. 278-388; KROMAYER and VEITH, 1931, p. 610ff; DE SANCTIS, 1917, p. 131-210; DELBRÜCK, 1990, p. 315-335; LAZENBY, 1978; SABIN, 1996; CONNOLLY, 1998, p. 183-188; GOLDSWORTHY, 2001; DALY, 2002; SABIN, 2007a, p. 183-186 and 2007b). However, despite the thorough research by generations of scholars, this battle remains in many ways puzzling. This is not only a result of the schematic nature of the surviving ancient accounts, with their many inherent gaps and contradictions, but also due to the sheer complexity of this massive engagement, in which more than 120.000 men took a direct part in the fight. ${ }^{3}$

Ancient tradition is unanimous in attributing the Roman defeat to the consul Terentius Varro and in the exculpation of his colleague Paullus. The former, a homo novus, has been caricatured as a demagogue from humble origins that precipitates himself into a decisive battle even though the circumstances were not favourable (Liv. 22.25.18-26.4; Plut., Vit. Fab. Max. 14; App., Hann. 17; Cass. Dio fr. 57.24). On the other hand, Paullus, who had already been consul in 219 $\mathrm{BC}$, is presented as a brave and intelligent military leader and an experimented senator (See Polyb. 3.19.12-13) who tries to moderate his colleague's rashness (Liv. 22.44.5). The consuls commanded on alternate days, as was usual when both mag-
2. See for example, G. De Sanctis, Storia dei Romani, Vol. III parte 2, Roma, 1917, 62ff.; J.F. Lazenby, Hannibal's War, Warminster, 1978, 83; G. Daly, Cannae. The Experience of Battle in the Second Punic War, London, 2002, 147 ff.

3. Roman numbers at Cannae were already debated in antiquity. Whereas Polybius (3.107.9-15) insists on the unprecedented number of legions enrolled by the Romans in the year 216 BC, Livy (22.36.24) records two different traditions, the one mentioned by Polybius and another according to which only ten thousand new soldiers were enlisted as replacements. Nevertheless, his numbers given for the Roman losses presuppose the higher totals. See Daly (2002 210 n.47). The lower total is defended by Brunt 1987, p. 419, n.2 following De Sanctis 1917, p. 119 and $131 \mathrm{ff}$. 
istrates were leading the same army. The main sources laud Paullus' prudence at the refusal of a first battle offer made by the Carthaginians, and attribute the acceptance of a second one to Varro's recklessness (Polyb. 3.113; Liv. 22.45.5-46.7).

Some scholars have rightly rejected the veracity of this tradition (BRISCOE, 1989, p. 52; DALY, 2002, p. $119 \mathrm{ff}$; CHAMPION, 2004, p. 201), whose origin lies perhaps in the historical work of Fabius Pictor (WALBANK, 1957, p. 448), a contemporary of these events, or in Polybius' wish to exculpate Paullus. In fact, Terentius Varro, far from being punished or reproached by the senate for his allegedly disastrous command, was -according to Livy- praised because he had not lost his faith in the republic (quod de re publica non desperasset - Liv. 22.61.14). Moreover, the senate kept him in command of Picenum from 215 until 213, and in 208 he was again appointed to a promagistracy in Etruria (ROSENTSTEIN, 1990, p. 201).

In his account of the fighting at Cannae, Polybius also tries to cast Aemillius Paullus in the best possible light, presenting the dead consul as a patriotic hero that sacrificed himself for Rome. Surprisingly, historians have not questioned Polybius' description of Paullus' role during the battle. Arthur Eckstein (1995, p. 38-39), for example, recognizes that Polybius presents a favorable image of Paullus that contrasts with that of Varro, but accepts the general accuracy of Polybius' account of Paullus actions on the Battlefield.

Before beginning an analysis of the Polybian narrative, it is necessary to briefly examine its main elements. The Greek historian begins his account with a description of the opposing army's battle order (Polyb. 3.113, cfr. Liv. 22.45.6-46.7). The consul Aemilius Paullus was in charge of the Roman right wing deployed next to the Aufidus River and consisting of the citizen cavalry, whereas Varro led the more numerous Italian allied cavalry on the left wing. The ex-consuls M. Atilius and C. Servilius commanded the infantry in the centre, which stood in an unusually deep formation. Hannibal placed the Gallic and Spanish cavalry under the leadership of Hasdrubal, one of his ablest officers, on the left wing facing the Roman citizen cavalry and outnumbering it by at least $2: 1$. On the other side, the Numidian cavalry was deployed on the right opposing the Italian allies. The infantry in the centre formed 
a strange convex line alternating Hispanic and Celtic units. At the flanks of this peculiar infantry formation stood, in two deep columns, the Lybian infantry equipped with Roman armour and weapons captured in Hannibal's previous victories.

Both armies also deployed in the field important contingents of light infantry, which opened the fighting with the usual skirmishes preceding the clash of the main forces (3.115.1). The real battle began with the cavalry wings next to the Aufidus River, where due to a lack of space, the usual cavalry tactics could not be applied as there was no room to perform outflanking manoeuvres, and consequently the opposed forces were only able to charge. Then, according to Polybius, when both forces clashed the troopers dismounted and fought on foot, which was an unusual Roman cavalry tactic in this period (See MCCALL, 2002, p. 36ff., 62ff.). The result was that the Carthaginians succeeded in driving the Romans back along the river and cut them down mercilessly (3.115.24). Polybius, however, does not comment Paullus' role at this stage of the battle.

The historian describes next the clash of the two main infantry bodies in the centre of the battlefield. Here, thanks to their superior numbers, the legionaries pushed the Carthaginian infantry back, whose convex line began to flatten fast (3.115.5-6). However, this was only a controlled retreat that closed the trap around the Roman centre. The legionaries advanced so far that their flanks became exposed to attack from the Libyan columns. When the Libyan soldiers then turned inwards to face the Romans, their advance began to lose momentum rapidly, as a compact formation could no longer be held and they were forced to fight on several fronts. (3.115.8-10). At this point of the narrative, we learn that although Paullus had taken part in the cavalry action on the right wing, he was still safe and sound (3.116.1). The historian also explains that the consul now wished to act upon the words he had addressed to the troops when he took command, and on seeing that the battle would be decided in the centre, he decided to ride there and throw himself into the fight (3.116.2-3).

Polybius continues his account of the battle with a description of the action on the Roman left wing, where the allied cavalry had been pinned down by the Numidians and their peculiar skirmishing tactics (3.116.5). The Gallic 
and Hispanic cavalry commanded by Hasdrubal, after cutting down the Roman citizen cavalry, crossed the battlefield behind the legionaries to attack the Roman left wing from the rear. The allied horse now disbanded and fled on seeing the imminent enemy charge, and although Polybius does not mention this fact, it is probable that Varro was carried away by the flight of his men. Hasdrubal left the persecution of the fleeing cavalry to the Numidians and began making several charges against the legionaries' rear. The Roman infantry was thus under attack from all fronts (3.116.6-8). At this moment, Polybius records Paullus' death, as he explains that the consul fell in the thick of the fighting after receiving terrible wounds (3.116.9). The Roman infantry resisted for as long as the legionaries could hold an organized defence line on every side, but under the extreme pressure of the enemy attacks they fell in disorder and were mostly killed on the spot where they stood. Among the few high-ranking Roman survivors was consul Varro, who, in Polybius' opinion, had disgraced himself by his flight (3.116.10-13).

As has been already pointed out, although many scholars reject Polybius' biased description of Varro's actions in the battlefield and of his responsibility for the defeat, they generally accept his version of Paullus' heroic behaviour as being essentially truthful. However, an analysis of the Polybian account of the battle just reviewed clearly shows the presence of internal contradictions and fictitious additions with respect to the dead consul's role in the fighting. It is noteworthy that ancient sources also differ considerably on their depiction of Aemilius Paullus' activities on the battlefield. Livy presents a completely different version, in which the consul is hurt at the beginning of the engagement by a stone thrown by an enemy slinger but continues to take a direct part in the fighting. Upon seeing defeat as certain, a Roman tribune offers the wounded consul his horse so he can escape, but Paullus prefers staunchly to die in the battlefield and sends this officer with a warning to the city of Rome so that the defences can be prepared in time (Liv. 22.49.1-12). In contrast, according to Appian, Paullus fought in the centre but with a chosen body of one thousand horses as his personal guard (App. Hann. 19). Therefore, in my opinion, it is clear that the ancient authors lacked direct and precise information about Paullus' conduct 
on the battlefield and this gave rise to different reports. In addition, the fact that he lost his life whereas his colleague was one of the few who could escape probably contributed to his stature being magnified. The ancient historians filled in the unknown details with different versions of his heroic death, which were influenced by Paullus' aristocratic lineage and his impressive background as a military leader. It should also be noted that in the year 216 BC Paullus was consul for the second time and that in his first tenure (219 BC) he had celebrated in triumph a distinguished victory over the Illyrians (BROUGHTON, 1957, p. 236).

The biggest concern about the Polybian account of Paullus' role lies in its inconsistencies. The fight next to the Aufidus River is described as being truly "barbaric" and ending with the Roman horse cut down mercilessly (3.115.2-4). However, Polybius maintains that Paullus survived this fight unharmed and that he was not carried away by the flight of the surviving troopers, as happened to his colleague Varro on the left wing. If Paullus really took part in the action leading the right wing, then it is difficult to see how he could both survive the clash and remain there and then be able to ride to the centre of the battlefield unimpeded. A Roman consul was an especially conspicuous figure on the battlefield, with his paludamentum (a purple cloak fastened at one shoulder worn by magistrates with imperium- (OAKLEY, 1997, p. 94-95; SAUER, 1949, p. 281-6)), his ornamented breastplate and helmet, and with the presence around him of several high ranking officers and attendants making it very unlikely that he could go unnoticed (DALY, 2002, p. 152). Enemy commanders were prized targets in all ancient battles, where the killing of an enemy leader could represent a crucial step towards victory and was accordingly one of the greatest and bravest deeds that any soldier or officer could perform. For example, both Polybius and Livy describe how, in the battle of Lake Trasimene, the Gallic warriors fighting for the Carthaginians quickly identified the consul Flaminius and made him the object of their attacks until they were able to take his life despite the courageous defence of the Roman legionaries (Polyb. 3.84.6, Liv. 22.6.1-4). Taking this into account, it is difficult to believe that Paullus could have been able to survive the 
defeat of his cavalry forces unharmed and moreover to remain active on the battlefield.

Another problematic point is how Polybius explains Paullus' resolution to ride to the centre and to fight with the infantry, supposedly due to his wish to act upon the ideas expressed in a speech given to the troops some days before the

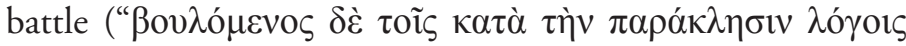
$\dot{\alpha} \kappa \circ \lambda$ ov́ $\theta \omega \varsigma^{\prime \prime}$ Polyb. 3.116.2). In fact, Polybius refers to the speech in some detail before giving his account of the fighting (Polyb. 3.108.2-109.13). Nevertheless, according to the historian, the main part of Paullus' speech consisted in an attempt to give the reasons for the previous defeats against the Carthaginians in order to induce confidence in the demoralized soldiers (3.109.3). A part of his address to the troops is quoted in the text verbatim, where the consul also reminds the legionaries that he does not need to exhort them because they are not mercenaries but men that fight for their own country and thus know the consequences that defeat would bring upon themselves and their families. What man (he asks) would not prefer to triumph in battle or, in the event that this is not possible, to die fighting rather than to witness the

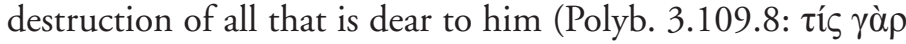

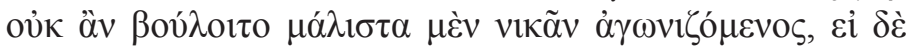

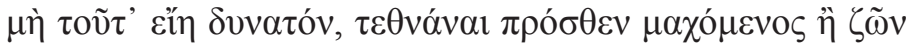

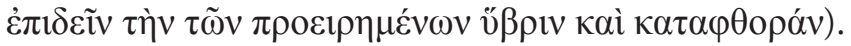

These are clearly the words upon which Paullus wished to act, and according to the historian he did just that. He preferred to fall heroically exchanging blows with the enemies, rather than to escape like Varro. The historian also adds that if there ever was a man who did his duty to the fatherland both throughout his life and in his final moments, this was L. Aemil-

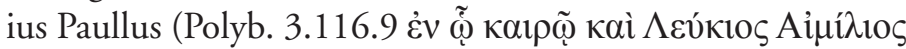

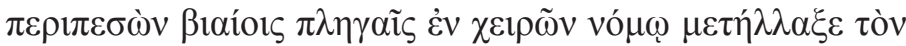

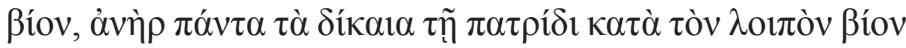

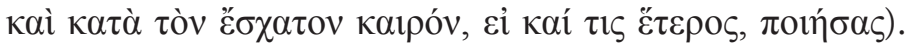
Here the tone is almost panegyrical, and the argument only the reproduction of a topos the heroic death of a commander in battle. However, this connection between Paullus' speech and his actions on the battlefield seems to be rather artificial, and even more so when it is accepted that ancient historians in the great majority of cases do not reproduce verbatim what 
was said on a given occasion, but give only a version of what could or should have been said. Then, at best, this is combined with the surviving information, if any is available, of what was actually said (MARINCOLA, 2007, p. 118-132; WALBANK, 1985, p. 242-61; WOOTEN, 1974, p. 23551; MCGING, 2010, p. 88-89). Thus, the degree of fidelity displayed by reported speeches in classical historiography is a highly debated question, but again Polybius' reputation in this respect is well above average. Indeed, for Walbank, Polybius is "entitled to our confidence that he made a determined effort to discover what was actually said" and "that any failure here and there is due to practical shortcomings rather than a deliberate betrayal of principle" (1957, p. 14).

The authenticity of the battle speeches reported by ancient historians has been particularly questioned because logistical considerations often render them unrealistic (HANSEN, 1993, p. 161-180 and 1998; ERHARDT, 1995, p. 120-121). In this case, however, Paullus addressed the troops some days before the battle in the Roman camp and therefore this makes it somewhat more plausible. Despite this, it is difficult to believe that Polybius would have had access to an accurate source of the consul's words. The content of the speech is rather stereotyped, and Polybius himself declares that Paullus said "what was fitting to the circumstances" (POLYB. 3.108.2; WALBANK, 1957, p. 442). Even if the speech is considered to be authentic, it is clear that Polybius could not have known Paullus' thoughts during the engagement, and even less be certain that his motivation to die on the battlefield rested on a wish to act upon the words he had addressed to the legionaries several days before. It seems that the historian uses these narrative resources here to magnify Paullus' figure, and as a result he is exculpated of any responsibility for the defeat and is presented as a heroic leader in the best Roman traditions.

Polybius' bias is easily understandable; he was a "hostage" to Rome as he owed his position and his access to the circles of the Roman elite entirely to the patronage and friendship of Scipio Aemilianus, who was in fact Aemilus Paullus' grandson. Thus, Polybius either elaborated the oral traditions of the Aemilii Paulli concerning his ancestor (as it would have been impolite for him to be overly skeptical about 
it) or he simply reproduced and adapted the content of one or several of his written sources. A. M. ECKSTEIN (1995, p. 9) is certainly right in arguing that the pro-Aemilian and pro-Scipionic Tendenz in Polybius' work should not be exaggerated, but it should not be minimized either, with Polybius' depiction of Paullus' actions at Cannae being a clear example.

Summing up, the contradictions inherent in the surviving ancient accounts concerning the role of Paullus at Cannae probably indicate that there was no direct or authoritative information available. This cannot be considered to be surprising, because it is difficult to believe that there could have been many, among the Roman survivors, who had witnessed all of Paullus' activities on the battlefield. If the consul really fought commanding the Roman right wing, as Polybius affirms, then it is hard to believe that he could have survived the fast extermination of his forces by Hasdrubal's cavalry.

\section{REFERÊNCIAS BIBLIOGRÁFICAS}

BRISCOE, John. The Second Punic War. In: ASTIN, Alan Edgar and WALBANK Frank (eds.). The Cambridge Ancient History (Vol. VIII). Cambridge: Cambridge University Press, 1989, p. 44-80.

BROUGHTON, Thomas Robert. The Magistrates of the Roman Republic (Vol. I). New York: American Philological Association, 1957.

BRUNT, Peter. Roman Manpower. Oxford: Oxford University Press, 1987.

CHAMPION, Craige B. Cultural Politics in Polybius' Histories. Berkeley: University of California Press, 2004.

CONNOLLY, Peter. Greece and Rome at War. London: Greenhill, 1998.

DALY, Gregory. Cannae. The Experience of Battle in the Second Punic War. London: Routledge, 2002.

DE SANCTIS, Gaetano. Storia dei Romani (Vol. III). Roma: Fratelli Bocca, 1917.

DELBRÜCK, Hans. History of the Art of War (Vol. I). In: Warfare in Antiquity. Trad. W.J. Renfroe. Lincoln: University of Nebraska Press, 1990. 
ECKSTEIN, Arthur M. Moral Vision in the Histories of Polybius. Berkeley: University of California Press, 1995.

EHRHARDT, Christopher. Speeches before battle?, Historia 44, pp. 120-121, 1995.

GOLDSWORTHY, Adrian. Cannae. London: Phoenix Press, 2001.

HANSEN, Mogens Herman. The Battle Exhortation in Ancient Historiography: Fact or Fiction? Historia, 42, 1993, p. 161-180.

HANSEN, Mogens Herman. The Little Grey Horse-Henry V's Speech at Agincourt and the Battle Exhortation in Ancient Historiography. Histos (4), electronic publication, 1998 (www.dur.ac.uk/Classics/histos/1998/hansen.html).

LAZENBY, John. Hannibal's War. Warminster: Aris and Phillips, 1978.

LEHMANN, Gustav Adolf. Untersuchungen zur historischen Glaubwürdigkeit des Polybios. Münster: Aschendorff, 1967.

MARINCOLA, John. Speeches in Classical Historiography. In: MARINCOLA John (ed.). A Companion to Greek and Roman Historiography. Oxford: Blackwell, 2007, p. 118-132.

MARSDEN, Eric William. Polybius as a Military Historian. In: Polybe, Entretiens sur l'Antiquite Classique XX. Geneve: Fondation Hardt, 1974, p. 269-301.

MCCALL, Jeremiah. The Cavalry of the Roman Republic. London \& New York: Routledge, 2002.

MCGING, Brian. Polybius' Histories. Oxford: Oxford University Press, 2010.

OAKLEY, Stephen. A Commentary on Livy (Books VI-X). Oxford: Clarendon Press, 1997.

POLYBII. Historiae. Transl. Ludwig Dindorf and Theodor Büttner-Wobst. Munich: K. G. Saur, 1998.

SABIN, Philip. The Mechanics of Battle in the Second Punic War. In: CORNELL, Tim; RANKOV, Boris; SABIN, Philip (eds.). The Second Punic War: a reappraisal. London: Institute of Classical Studies, 1996.

SABIN, Philip; Lost Battles. Reconstructing the Great Clashes of the Ancient World. London: Hambledon Continuum, 2007a. SABIN, Philip; Land Battles. In: SABIN, Philip; VAN WEES, Hans; WHITBY, Michael (eds.). The Cambridge His- 
tory of Greek and Roman Warfare (Vol. I). Cambridge: Cambridge University Press, 2007b, p. 399-434.

SAUER, Hertha. Paludamentum, Realencyclopädie der classischen Altertumswissenschaft, 18.3, cols. 281-86, 1949.

TOYNBEE, Arnold. Hannibal's Legacy (Vol.2). London: Oxford University Press, 1965.

VEITH, Georg; KROMAYER, Johannes. Antike Schlachtfelder in Italien und Afrika, vol. 3, part 1, Berlin, Weidmannsche Buchhandlung, 1912.

VEITH, Georg; KROMAYER, Johannes. Antike Schlachtfelder, vol. 4, Berlin, Weidmannsche Buchhandlung, 1924-31.

WALBANK, Frank. A Historical Commentary to Polybius (Vol. I). Oxford: Oxford University Press, 1957.

WALBANK, Frank. Speeches in Greek Historians. In: WALBANK, Frank. Selected Papers: studies in Greek and Roman History and Historiography. Cambridge: Cambridge University Press, 1985, p. 242-61.

WOOTEN, Cecil. The Speeches of Polybius: an insight into the nature of Hellenistic Oratory, AJPh 95, p. 235-51, 1974.

Recebido em março de 2014. Aprovado em julho de 2014. 